\title{
Nitrogen-Containing Heterocycles in Agrochemicals
}

\section{Eman A Al-Harbi* and Wafaa Ahmed Gad}

Department of Chemistry, Taibah University, Saudi Arabia

Submission: May 06, 2018; Published: May 22, 2018

"Corresponding author: Eman A Al-Harbi, Department of Chemistry, Taibah University, Al-Madinah Al-Minawara, Saudi Arabia, Email: eman.a.alharbi@hotmail.com

\section{Introduction}

Nitrogen-Containing heterocyclic compounds are the most abundant and integral scaffolds that occur in a variety of synthetic drugs, bioactive natural products, pharmaceuticals and agrochemicals.

Lei Zhou et al. [1] reported the synthesis and the bacterial activity of pyridinium -5 - trifluoro-methylpyrazoles $\left(1_{\mathrm{a}-\mathrm{f}}\right)$ bearing 1,3,4 oxadiazole moiety. These thioethers exhibited significant inhibitory activity against pathogenic bacteria Xanthamonas oryzae pv. oryzae (Xoo), Ralstonia solanacearum and Xanthomonas axonopodis pv.citri (Xac).<smiles></smiles>

$$
\mathrm{n}=3,4,6,8,10,12
$$

$\left(\mathbf{1}_{\mathrm{a}-\mathrm{f}}\right)$

Benzo[d] imidazolyl tetrahydropyridine carboxylates $(2$ ac) have been prepared and were evaluated for their antifungal activity against Aspergillus niger (ATCC 16404). These compounds are significally toxic toward the fungi. Compounds with the electron- donating methoxy group on the phenyl ring are highly toxic [2].

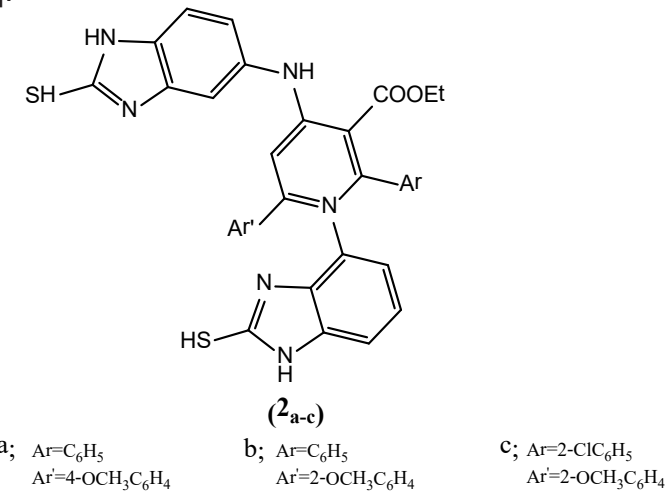

Olyinka O Ajani etal. [3] synthesized benzimidazole derivatives by ecofriendly method and examined their antimicrobial properties for future drug and agrochemical developments. large zones of inhibition were noticed for compounds $\left(3_{\mathrm{a}-\mathrm{c}}\right)$ and $\left(4_{\mathrm{a}}\right)$ against Bacillus Licheniformis, compounds $\left(3_{\mathrm{b}, \mathrm{d}}\right),\left(4_{\mathrm{b}}\right)$ and $\left(5_{\mathrm{a}, \mathrm{b}}\right)$ against Proteus Vulgaris and compounds $\left(3_{\mathrm{a}-\mathrm{c}}\right),\left(4_{\mathrm{a}}\right)$ and $\left(5_{\mathrm{c}}\right)$ against Pseudomnas acruginosa.
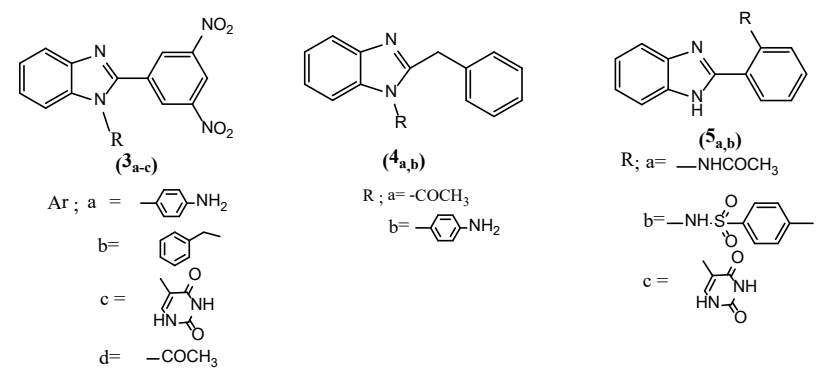

Gregory Landellea et al. [4] reported the synthesis of imidacloprid and thiacloprid containing either 6- trifluoromethoxy or 6-difluoromethoxy -pyridin-3-yl methyl moieties $\left(6_{\mathrm{ab}}\right)$ and $\left(7_{a b b}\right)$, respectively. $\mathrm{F}_{2} \mathrm{HCO}$-Imidacloprid $\left(6_{\mathrm{b}}\right)$ is more active in vivo against green-peach aphid (M. persicae) than $\mathrm{F}_{3} \mathrm{CO}$ derivatives $\left(6_{\mathrm{a}}\right)$, both derivatives are less active than imidacloprid. $\mathrm{F}_{3} \mathrm{CO}-$ Thiacloprid ( $7_{\mathrm{a}}$ ) is more active in vivo against $M$. persicae than $\left(7_{\mathrm{b}}\right)$. Both derivatives $\left(7_{\mathrm{a}, \mathrm{b}}\right)$ are much less active than thiacloprid.

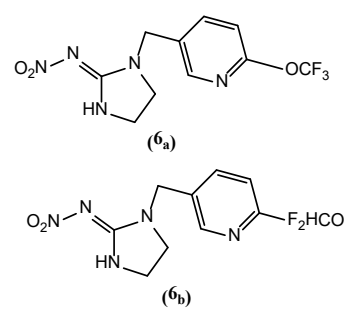<smiles>N#CN=C1SCCN1Cc1ccc(OC(F)(F)F)nc1</smiles><smiles>N#CN=C1SCCN1Cc1ccc(F)nc1</smiles>

(7b)
Compounds $\left(2_{\mathrm{a}, \mathrm{b}}\right)$ inhibit $14-\alpha$ demethylase in sterol biosynthesis pathway of the fungi 2018 .

Stephan et al. [5] synthesized 4-(2,5-dichlorothiophen-3-yl)1,3-dithiolan-2-ylidene)methyl)-1H-imidazole derivatives $\left(8_{\mathrm{a}, \mathrm{b}}\right)$ 
inhibited 14- $\alpha$-demethylylase in the sterol biosynthesis pathway of the fungi.<smiles>N#CC(=C1SCC(c2cc(Cl)sc2Cl)S1)n1ccnc1</smiles><smiles>C#CCOc1ccc(C2CS/C(=C(/C#N)n3ccnc3)S2)c(Cl)c1F</smiles>

$\left(\mathbf{8}_{\mathrm{a}, \mathrm{b}}\right)$

The above investigations open the route to a new acess to bioactive ingredients and their further evaluation, which could possibly lead to large activity enhancements.

\section{References}

1. Lei Zhou, Pei-Yi Wang, Jian Zhou, Wu-Bin Shao, He-Shu Fang, et al. (2017) Antimicrobial activities of pyridinium-tailored pyrazoles bearing 1,3,4-oxadiazole scaffolds. J Saudi Chem Soc 21(7): 852-860.
2. Anisetti Ravindernath, Malladi S Reddy (2017) Synthesis and evaluation of anti-inflammatory, antioxidant and antimicrobial activities of densely functionalized novel benzo[d] imidazolyl tetrahydropyridine carboxylates. Arabian J Chem 10(Supplement 1): s1172-s1179.

3. Olayinka O Ajani, Olayinka O Tolu-Bolaji, Shade J Olorunshola, Yuxia Zhao, Damilola V Aderohunmu (2017) Structure-based design of functionalized 2-substituted and 1,2-disubstituted benzimidazole derivatives and their in vitro antibacterial efficacy. J Adv Research 8(6): 703-712.

4. Gregory Landellea, Etienne Schmitta, Armen Panossiana, Jean-Pierre Vorsb, Sergiy Pazenokc, et al. (2017) Tri- and difluoromethoxylated $\mathrm{N}$-based heterocycles-Synthesis and insecticidal activity of novel F3COand F2HCO-analogues of Imidacloprid and Thiacloprid. J Fluorine chem 203: 155-165.

5. Stephane Jeanmart, Julien Gagnepain, Pulakesh Maity, Clemens Lamberth, Fredrik Cederbaum, et al. (2018) Synthesis and fungicidal activity of novel imidazole-based ketene dithioacetals. Bioorg Med Chem 268(8): 2009-2016.

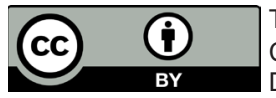

This work is licensed under Creative Commons Attribution 4.0 License DOI: 10.19080/ARTOAJ.2018.16.555986

\begin{tabular}{|l|}
\hline \multicolumn{1}{|c|}{ Your next submission with Juniper Publishers } \\
will reach you the below assets \\
- Quality Editorial service \\
- Swift Peer Review \\
- Reprints availability \\
- E-prints Service \\
- Manuscript Podcast for convenient understanding \\
- Global attainment for your research \\
- Manuscript accessibility in different formats \\
( Pdf, E-pub, Full Text, Audio) \\
- Unceasing customer service \\
Track the below URL for one-step submission \\
https://juniperpublishers.com/online-submission.php \\
\hline
\end{tabular}

